AMERICAN JEWISH COMMUTEE, American Jewish Year Book 1999. A Record of Events and Trends in American and World Jewish Life

New York, 1999, 754 p. (tablx., index)

\title{
Régine Azria
}

\section{CpenEdition}

\section{Journals}

Édition électronique

URL : http://journals.openedition.org/assr/20613

DOI : $10.4000 /$ assr.20613

ISSN : $1777-5825$

Éditeur

Éditions de l'EHESS

Édition imprimée

Date de publication : 1 juillet 2000

Pagination : 111

ISBN : 2-222-96691-4

ISSN : 0335-5985

\section{Référence électronique}

Régine Azria, «AMERICAN JEWISH COMMUTEE, American Jewish Year Book 1999. A Record of Events and Trends in American and World Jewish Life ", Archives de sciences sociales des religions [En ligne],

110 | avril-juin 2000, document 110-51, mis en ligne le 19 août 2009, consulté le 21 septembre 2020

URL : http://journals.openedition.org/assr/20613 ; DOI : https://doi.org/10.4000/assr.20613

Ce document a été généré automatiquement le 21 septembre 2020.

(C) Archives de sciences sociales des religions 


\section{AMERICAN JEWISH COMMUTEE, American Jewish Year Book 1999. A Record of Events and Trends in American and World Jewish Life}

New York, 1999, 754 p. (tablx., index)

Régine Azria

\section{RÉFÉRENCE}

AMERICAN JEWISH COMMUTEE, American Jewish Year Book 1999. A Record of Events and Trends in American and World Jewish Life,New York, 1999, 754 p. (tablx., index)

1 Outre ses rubriques habituelles, cette livraison 1999 se signale par un substantiel article sur l'éducation juive aux États-Unis (sous la signature de Jack Wertheimer) ainsi que par un bilan contrasté de l'immigration et de l'intégration des juifs de l'ex-Union soviétique en Israël durant les années 1990 (Elazar Leshem et Moshe Sicron). En ouverture de son analyse annuelle, Sergio Della Pergolla indique qu'à la fin de année 1997, l'estimation de la population juive mondiale dépassait tout juste les 13 millions. 